EUI-BIB

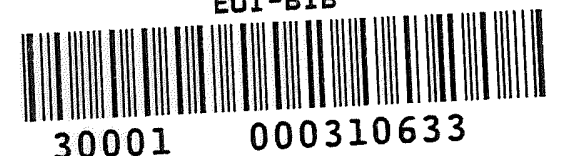

EUROPEAN UNIVERSITY INSTITUTE, FLORENCE DEPARTMENT OF ECONOMICS

\author{
I \\ EUI WORKING PAPER N $0.85 / 194$ \\ THE SHARE ECONOMY: \\ PLAUSIBILITY AND NIABILITY \\ OF WEITZMAN'S MODEL \\ by \\ Domenico Mario Nuti
}

BADIA FIESOLANA, SAN DOMENICO (FI) 
All rights reserved.

No part of this paper may be reproduced in any form without

permission of the author.

(C) Domenico Mario Nuti.

Printed in Italy in October 1985 European University Institute Badia Fiesolana

- 50016 San Domenico (FI) Italy
THE SHARE ECONOMY: PLAUSIBILITY AND VIABILITY OF WEITZMAN'S MODEL

$$
\begin{gathered}
\text { D.M. Nuti } \\
\text { European University Institute, } \\
\text { Florence. }
\end{gathered}
$$

SUMMARY

In the last two years M.L. Weitzman (M.I.T.) has been proposing the replacement of the fixed wage contract by a form of generalised sharing contract whereby at least a substantial component of workers' earnings is made of a stake in their enterprise performance. This institutional change is expected to guarantee the achievement and maintenance of full employment of labour without either inflationary pressures or sacrifices in real wages; on the contrary; the general price level would fall and real wages would increase, due to output expansion in conditions of monopolistic competition between firms. These results derive from the decoupling of the marginal cost of labour from the level of average earnings, which is implicit in the sharing contract.

In this paper a: summary of the proposal and a comparison with other share formulas are followed by a number of critical reflections. First the plausibility of Weitzman's assumptions is challenged, for the implicit neglect of keynesian and classical unemployment, of the persistent inflationary feedbacks of full employment and, above all, the lack of workers' participation in enterprise decision making which is postulated by the model in spite of continued full employment. Then the viability - understood as institutional stability - of Weitzman's model is questioned even within the framework of its own assumptions. It is argued that the model has systemic instability because of its proneness to mergers in the short run, the entry of non-income-sharing new firms in the medium run and, above all, a built-in tendency to revert to the wage economy in the long run. In any case, if Weitzman's model is accepted, the gradual introduction of a wage subsidy is shown to have the same beneficial effects of income sharing without any of its drawbacks. 
THE SHARE ECONOMY : PLAUSIBILITY AND VIABILITY OF WEITZMAN'S MODEL *

D.M. Nuti

European University Institute,

Florence.

1. Introduction

The persiptence and apparent intractability of both large scale unemployment and inflation coexisting in advanced capitalist countries over the last decade have stimulated a number of new or revamped policy proposals, mostly altering the terms of employment contracts, in an attempt to cure one illness without aggravating the other. These proposals range from the introduction of wage indexation formulas at times of accelerating inflation to their abolition when inflation decelerates; from the collectivisation of unemployment (i.e. "work sharing") to synchronised collective bargaining; from tax-based incomes policy to direct wages and prices control - with or without formal or informal stipulations of neo-corporatist social pacts to make them acceptable to workers as part of a package.

The latest proposal in this vein is from M.L. Weitzman (1983, $1984 \mathrm{a}, 1984 \mathrm{~b}, 1985)$, advocating the replacement of the fixed wage contract by a form of generalised (i.e. economy-wide) sharing contract whereby at least a substantial component of workers' earnings is made of a stake in their enterprise performance. The idea is not new: forms of income sharing or performance related payments abound in modern capitalism

\footnotetext{
* Paper presented at the Arne Ryde Symposium on "Incentive mechanisms and problems in major economic systems", held by Lund University at Frostavallen, 26-27 August 1985. An earlier draft was presented at the Working Group on Comparative Economic System, EUI, Florence, on 12 April 1985; and at a seminar at the Faculty of Economic Sciences, Warsaw University, on 26 April seminar at the Faculty of Econic Sciens, 1985. Acknowledgents are due to Will Bartlett, John Cable, Pierre Dehez, Jacques Drèze and Saul Estrin for helpful comments, though of course they are not responsible for errors and opinions contained in this paper. Thi research is part of an EC funded project on "The impact of workers" participation schemes on enterprise performance" conducted by the author at the EUI.
} 
(cooperatives, productivity bargaining, workers' shareholdings), in pre-capitalistic formations (share-cropping, sliding scales) and post-capitalistic experiments or projects (like the Yugoslav system, the labour-managed firm theorised by Ward, 1958 and Vanek, 1970; or Hertzka's utopia, 1891). What is new in Weitzman's proposal is the specific rejection of workers' participation in decision-making as a necessary feature of income sharing; the wide scope of envisaged implementation, since the proposal is expected to apply to the bulk of employment in all sectors of the economy in order to produce the desired macroeconomic benefits; and the emphatic, enthusiasm, to the point of exaggerated assertiveness, with which the proposal is put forward as the total and miraculous answer to the major economic problem of our time: stagflation. Weitzman's evangelism has infected others ${ }^{1}$ and received wide press coverage ${ }^{2}$.

In this paper a summary of the proposal (section 2) and a comparison with other share formulas (section 3) are followed by a number of critical reflections. First the plausibility of Weitzman's assumptions is challenged, for the implicit neglect of keynesian and classical unemployment (section 4) and of the persistent inflationary feedbacks of full employment (section 5) and, above all, the lack of workers' participation in enterprise decision making under continued full employment (section 6). Then the viability of Weitzman's model is questioned even within the framework of its own assumptions; it is argued that the mode1 has systemic instability because of its proneness to mergers in the short

1. Pre-publication comments on Weitzman's book (1984a) by R.M. Solow, J.E. Roemer and J.E. Meade, printed in the book's cover, uncharacteristically depart from the usually sober style of these authors: "... marvellous book ... daring ... practical" (Solow); "One of the most exciting books in economics ... the most profound intervention in unemployment policy of capitalist countries since Keynes's" (Roemer); "Important, stimulating, ... persuasive ... should be read and inwardly digested by every concerned economist, administrator and politician" (Meade)

2. See for instance S. Brittan in the Financial Times, Monday 25 February 1985, p.12; C.P. Alexander in Time Magazine, 20 May 1985. run (section 7), the entry of non-income-sharing new firms in the medium run (section 8) and, above all, a built-in tendency to revert to the wage economy in the long run (section 9). The last section sums up the arguments and assesses their impact on the proposal. It should be stressed that the objections raised do not refer to income sharing as such, only to its miraculous properties as postulated by Weitzman, and to its introduction in isolation without the parallel progress of workers' participltion in decision-making.

\section{Weitzman's mode1}

The model proposed by Weitzman is the macroeconomic extension of enterprise behaviour in conditions of monopolistic competition in the product market, replacing wage labour by net revenue sharing workers. The formulation presented here is slightly modified, without loss of generality, to allow for the comparison of alternative labour contracts.

The monetary revenue of the firm, $R$, net of all non-labour costs, is a function of output and, therefore, indirectly of the employment L necessary to obtain that output for the given amount of fixed capital at the firm's disposal:

$$
\mathrm{R}=\mathrm{R}(\mathrm{L}) \text {, }
$$$$
\text { at } L_{b}, R^{\top}=0 \text { and } R^{m}<0 \text {. }
$$

Net revenue per worker $R / L$ is a function of employment; at first it will rise because of the presence of overhead costs, up to the employment level $L_{c}$, then it will fall with output increases because of falling marginal revenue (which will dominate even the possible presence of increasing returns to scale as long as total revenue beyond some point fills faster than costs, with respect to output; a sufficient condition is demand saturation at some level of output, which is a standard feature of monopolistic competition models). For simplicity inputs other than labour and fixed capital are ruled out. Therefore: 

(2)
$R / L=f(L)$,
$f^{\prime} \geqslant 0$ for $I \leqq L$
(at $\left.L_{c}, f=R^{\prime}\right)$

Money earnings e per worker, in their general form, are defined as composed of a fixed component $\underline{a}$ and a share $\underline{b}$ of net revenue per worker $\mathrm{R} / \mathrm{L}$ after the deduction of $\underline{\mathrm{a}}$ :

$$
e=a+b(R / L-a) \text {, where } \underline{a} \geqslant 1 ; 1>\underline{b} \geqslant 0 \text {. }
$$

The actual values of $\underline{a}$ and $\underline{b}$ define alternative labour contracts, namelyl wage labour corresponds to $\underline{a}=\underline{w}, b=0$; income sharing corresponds to $a \geqslant 0$ and $1>b>0$.

Profit-maximising firms employing wage labour under the postulated monopolistic competition will employ labour up to employment level $\mathrm{L}_{\mathrm{w}}$ where $R^{\prime}=w^{\prime}$; those paying labour under a mixed (fixed/sharing) contract for $a>0$ and $1>b>0$ will employ workers up to the level $L_{s}$ at which $R^{\prime}=a$; while with profit maximisation under pure income sharing ( $a=0$, $1>b>0)$ workers will be employed up to the point where $R^{\prime}=0$, i.e. up to the level $\mathrm{L}_{\mathrm{b}}$.

On the basis of this simple analysis Weitzman puts forward the following propositions:

i) for any level of workers' earnings $e=a+b(R / L-a)$ the revenue sharing enterprise will offer more employment than the wage labour enterprise facing $w=e$ (since $a=w-b(R / L-a)<w)$, so that the switch from $a$ given wage to a formula initially yielding the same level of earnings in the economy as a whole will lead to a higher demand for labour, i.e. that corresponding to $w=a$, as if wages had fallen by ( $w-a) / w$ (under pure sharing, i.e. $a=0$, the same labour demand will obtain that in a wage economy would correspond to zero wages).

ii) money earnings per worker would fall, but the impact on employment would be greater than the effect of wage flexibility (which is "desirable per se", Weitzman 1984a, p.143), because of the decoupling of trends in average versus marginal labour cost, the first (=e) not having to fall as much as the second (=a) as is the case, instead, for wage labour. Workers' total money earnings in the economy, however, would not necessarily fall, while real earnings (and real incomes all round) in the economy as a whole would actually increase, if the switch to a sharing contract was economy-wide, since the proportional price fall would be greater than the fall in earnings in the transition from wage to income sharing (because the elasticity of the $R^{\prime}$ function is smaller than that of the net revenue per worker curve over the relevant range).

iii) the labour demand expansion resulting from the economy-wide switch from wage contracts to income-sharing is expected, by Weitzman, to be greater than existing unemployment. Thus the switch would generate not only full employment of labour, but a sizeable permanent excess demand for labour, which would absorb all or part of occasional or cyclical demand falls in the economy without inducing firms to pay inflationary wage rises because these would violate profit maximisation conditions; indeed, higher employment would have a deflationary impact on prices via greater output.

iv) In the long run the same level of employment, output, prices and earnings would prevail as in a wage economy, earnings gradually settling down at the full employment marginal revenue product of labour and prices following suit. Excess demand for labour, however, would be maintained because the presence of a sharing component in full employment earnings will maintain the marginal labour cost to the firm (=a) below the full employment marginal revenue product of labour $\left(w^{*}=e^{*}=a+b(R / L-a)>a\right)$.

Weitzman considers, in passing, alternative sharing formulas, all linking workers' pay to firm-specific indicators including the price of output, revenue, value added or profit per worker, gross or net. Strangely, he regards profits as more stable over time (1984a, p.137) as well as a truer measure of the firm's economic condition. He favours revenue because it is "inherently a more precise concept than profits and might be better to use for that reason" (ibidem). The essence of the sharing contract is that "if workers are laid off or quit, the remaining employees are paid more, whereas if new workers are hired, all employees are paid less" (1984a, p.83); thus "a share contract is defined to be any compensation 
function" such that "the level of workers pay is inversely related to the level of firm's employment" (1983, p. 768). Weitzman refers to share contracts as involving a change in the "numeraire" of the wage contract (1984a, pp. 763-4) but this is a misnomer since there is normally a difference between a fixed payment (denominated in whatever units) and a performance related payment; the two are the same thing only for sliding scale contracts in which the money wage is indexed to product price, and the notion of a change in numerraire is misleading for the general class of sharing contracts as defined above ${ }^{1}$.

The switch from"wage to incone sharing would then produce the costless and simultaneous achievement - hitherto believed impossible of full employment, stability in the face of sudden demand shocks and the control of inflation (which could then be delegated to monetary policy without fear of adverse effects on employment). "A share system looks very much like a 'labour shortage' economy. Firms cruise around like vacuum cleaners on wheels, searching in nooks and crannies for extra workers to suck in at existing compensation parameter values. Such an economy is inherently recession resistant. Every share firm wants to hire more workers at the equilibrium parameter rates, making temporary additional profits by absorbing any incipient pockets of unemployment that arise or can be found" (1983, p. 777). "It is especially difficult ... for cost-push inflation to get even a toehold in a share firm. Any raising of labor's pay above the going level is a temporary effect that the firm will automatically offset, over time, by hiring new workers attracted to its higher compensation and by flooding its product market with low-priced output" (1984a, p. 117). Moreover, 'There is another, more subtle benefit of permanent excess demand for labor: it gives dignity to the working man and woman, the sense of being significant, useful members of society ..." (1984a, p.121), due to non-price competition for workers by firms; "gain

1. Weitzman refers to wages as sometimes "rigidly indexed to money ..." (1983, p. 780) whereas money is the one thing to which money wages or any other money payments cannot be indexed by definition. sharing ... can boost employee morale, increase worker participation, improve labor-management relations, foster a sense of partnership, raise productivity and so forth" (1984a, p. 142). If the whole world were to adopt sharing schemes we would get "strong export-led growth in an enduring world economic boom" (1984a, p. 120). Wage labour is a "perilous anachronism" (ibidem, p. 46) while the proposed system is "The superior profit-sharing variant of capitalism ..." (1985, p.44).

Why, then, is this wondrous institution not used more widely in economies plagued by precisely the problems which it is alleged to cure? Because, Weitzman explains, the achievement of full and more stable employment with lower inflation depends on the nation-wide or at any rate large-scale diffusion of sharing schemes, which have no attraction for the individual firm and its employees. "The firm and its workers do not have an incentive to consider the macroeconomic implications of the contract form they are selecting" (1984a, p. 124); there is an "externa1ity", a "public good" or a "market failure" involved (ibidem, p. 123). Therefore it is necessary to undertake "a high priority, vigorous national program stressing awareness, education and information to infuse a sense of social responsibility into the collective bargaining process" (ibidem, p. 128); to introduce fiscal incentives lightening the tax burden on the share component of earnings (ibidem, p. 130) and to protect firms and unemployed workers from restrictive employment practices favoured by employed workers (ibidem, p. 133). In Weitzman's own words, "This is supply-side economics par excellence" (ibidem, p. 132).

\section{A comparative analysis}

It is interesting to compare Weitzman's analysis of sharing contracts' properties with the standard treatment of income sharing enterprises in order to understand both the specific features of Weitzman's proposal and the ultimate source of its originality. Two models are 
relevant for comparison since they both replace wage with a net revenue share: the dominant Ward-Domar-Vanek model of the labour-managed cooperative (Ward, 1958; Domar, 1966; Vanek, 1970) and the Hertzka-Breit -Lange model of workers' free access to employment in the firms of their choice (Hertzka, 1891; Breit-Lange, 1982; for an up-to-date bibliography on labour-managed firms and employee participation see Bartlett-Uvalic, 1985)

Both models envisage enterprises operating in market economies and replacing labour wage with shares in net revenue; indeed workers' earnings from labour are derived exclusively from share income $(a=0)$ and the whole net revenue of the enterprise can be distributed $(1 \geqslant b>0)$. The share $\underline{b}$ of net revenue to be distributed to workers is decided by employees through self-management organs (in Hertzka's model always $b=1$ ). In the Hertzka-Breit-Lange model any worker has the legal right to be employed by any firm of his choice at its average distributed net revenue per worker; in the Ward-Domar-Vanek model, on the contrary, the size of employment is decided exclusively by those already employed.

Optimising behaviour in the Ward-Domar-Vanek takes the form of net revenue per worker maximisation through workers' control over the size of employment, or rather membership, of the cooperative. The result is the opposite of Weitzman's and consists in a restrictive employment policy stopping recruitment, in equilibrium, at $L_{c}$ (where $f=R^{\prime}$ ); therefore in the short run employment is lower and full employment can only be reached, in the long run, through the entry of new and the exit of old firms. The short run is characterised by, instead of stability, perverse response to output price (because a price rise starting from equilibrium raises average above marginal net revenue thus encouraging a reduction instead of an increase in membership and viceversa) and to fixed capital rental (though there are a number of mitigating factors, see Vanek, 1970). Thus a small cooperative sector behaving in this fashion will have an anticyclical influence but, if extended to the whole economy, the system will be highly unstable. Unlike Weitzman, the whole literature on workers' income participation schemes has postulated that these are paralleled by at least some workers' voice in decision making, expressing concern directly or vicariously for the level of $\mathrm{R} / \mathrm{L}$ and exercising restraint on the size of employment (on this see section 6 below).

The Hertzka-Breit-Lange model ensures the elimination of involuntary unemployment through workers' access to any firm of their choice as does the later Weitzman model. However in Weitzman's "labour shortage" scenario workers have de facto access to any firm because of the postulated permanent excess demand for labour, whereas in the Hertzka-Breit-Lange model it is their access de jure that is the source, and not the consequence, of full employment. In both models the actual level of net earnings per man is equalised in the economy as a whole by workers' mobility across firms, whereas marginal products (and marginal revenue products) of labour are bound to differ across firms (but see section 7 below and Nuti, 1983). On the contrary, in the Ward-Domar-Vanek model average revenue per worker will be equalised only slowly through the entry and exit of firms, while within each firm marginal and average revenue per worker will tend to be in equilibrium (save for possible limits to the cooperative's ability to reduce membership in the short run).

\section{Plausibility: i) neglect of keynesian and classical unemployment}

Throughout Weitzman's analysis there is an assumption that unemployment is neither keynesian nor classical implicit in the notion that lower wages are sufficient to ensure full employment. Classical unemployment, here, is understood as a state in which the marginal product of labour reaches zero before full employment because fixed equipment is not sufficient to provide employment for everybody, regardless of the 
wage level. Keynesian unemployment is a state in which the marginal revenue product of labour reaches zero before full employment in spite of positive physical productivity of labour because aggregate demand - whether in money terms or, worse, in real terms - is insufficient.

The very notion of firms facing a given demand curve unrelated to the overall employment in the economy is a totally inadequate microfoundation for any kind of macroeconomics, though Weitzman makes an occasional reference to possible multiplier effects elsewhere of the higher level of employment reached in firms switching from wage to sharing ${ }^{1}$. These effects would actually strengthen Weitzman's case for sharing contracts, but the impact of a switch to those contracts on aggregate demand would be also partly negative, at least in the short run, through investment behaviour. In the long run we can accept Weitzman's contention that the opportunity cost of labour would be the same under both type of contracts and, therefore, the same techniques would be favoured (1984a, pp. 90-91; investment is not considered in any of his other writings on the subject); but in the short run the essence of the sharing contract is precisely the lowering of the opportunity cost of labour below the equivalent wage for the same level of earnings; thus equipment will be scrapped later, formerly obsolete equipment might be reinstated if available and new techniques, embodied in new equipment which would have been introduced under wage contracts, will not be for equivalent sharing contracts. Empirical evidence on the relationship between employment and wage levels, whether in the short or the long run, is inconclusive, and it cannot be taken as a matter of course that higher employment will be generated by a lower marginal cost of labour.

It is true that the fall in average earnings associated with lower marginal cost of labour under sharing contracts is not as large as

1. "Now as each firm expands, its new workers spend their wages on the products of other firms creating new demand .... and encouraging further expansion" (Weitzman, 1983, p. 764). This implies upward shifts of demand curves, with possible inflationary implications (see section 5). the fall which would be necessary under wage contracts to reach the same effect and, therefore, the adverse impact of lower money earnings on consumption monetary expenditure is not as great as it would be if the same marginal cost of labour was to be achieved in a wage economy. It is also true that in an economy of universal monopolistic competition à la Weitzman higher employment is associated with lower prices (as long as it is not achieved through the upward shift of demand curves as would be so in the case of greater government expenditure) and, therefore, lower money earnings would represent higher real earnings and actually boost real consumption demand. Nevertheless it still remains a matter of assumption and, therefore, of faith that the postulated position of demand curves for all of the enterprises in the economy - whether these curves are fixed or move as a result of the switch to sharing contracts - is such that aggregate demand for labour is at least as large as supply (which in turn might also be affected, either way, by a change in money and real earnings associated with the switch), at least as long as and the marginal cost of labour is not actually zero. Besides, it is sufficient to postulate kindred demand curves (for instance, kinked demand curves) to open the possibility of discontinuities in marginal net revenue per worker and a zero response of employment, even for $a=0$.

It is also a matter of assumption that there is enough equipment in the economy to provide full employment of labour. This used to be a standard assumption in the keynesian approach, likely to be satisfied for relatively short lived fluctuations of output and employment; but now, after over a decade of protracted and drastic recession, the closure, dismantling and demolition of plant on a large scale openly visible, for instance, in the landscape of the West Midlands or Northern France, it is unlikely that an expansion of labour demand would find matching equipment on the required scale.

It might be retorted that these objections invalidate Weitzman's claim that sharing contract can deliver full employment, but not the 
claim that they lead to higher employment than equivalent earnings under a wage regime, within the bounds set by either keynesian aggregate demand or the availability of plant. But aggregate demand is not necessarily invariant with respect to the kind of labour contract prevailing in the economy and the adverse impact on investment might more than offset the expected boost of real consumption demand. And, if capital equipment is a binding constraint before full employment is reached, then public policy should encourage investment, instead of promoting measures, like sharing contracts, which are acknowledged to discourage it.

\section{Plausibility: ii) persistent inflationary trends}

In the sharing model three factors are expected to keep inflation under control. First, firms refrain from raising prices because this leads to the equiproportional increase in the sharing component of earnings, thus reducing the advantage obtainable from price rises. Second, firms refrain from raising wages because this would go against profit maximisation: if they can get hold of the labour they want they have no incentive to raise wages, while if they are labour-constrained they would lower their profit by offering more than the going earnings rate to workers already employed as well as workers attracted from other firms. Third, if they did pay higher earnings than the going rate and managed to ease their employment constraint the concomitant output expansion would cause a fall in output price, turning a potentially inflationary move into a deflationary one and teaching firms not to bid up earnings in the labour market in spite of over-full employment.

Suppose that the switch from a wage to a sharing contract does lead to an expansion of employment and real output of both consumption and investment up to full employment (i.e. the objections raised in the previous section do not apply). Any feedback of real income on demand of the kind contemplated by Weitzman (1983, p. 764, quoted in the last footnote above) through multiplier effects, or accelerator effects, or both interacting in the familiar way, will shift upwards the firms' demand curves, unless all demand is totally income-inelastic. This recreates the possibility - if not the certainty - of output and employment expansion being inflationary, recreating the unemployment/ /inflation dilemma which sharing contracts are expected to eliminate. The actual terms of this dilemma would be somewhat improved by sharing formulas because output expansion along a given demand curve would not be inflationary but any upward shift of demand curves due to feedbacks of real income on demand would be just as inflationary as any other shift of that kind, including that obtained through increases in government expenditure.

If the sharing scheme is successful in reaching full employment without inflation it is unlikely to maintain this achievement in the face of the postulated persistent excess demand for labour at full employment. Persistent overfull employment is bound to raise the bargaining power of workers as well as their militancy regardless of the official policy of Trades Unions or even their existence. Although an individual firm will not have an incentive to bid up wages in spite of labour shortages, overfull employment conditions are bound to force all firms to concede higher money wages, which will push up prices through the uplift of demand curves and/or through firms' mark-up pricing, without any restraining impact of output on prices because aggregate real income is labour-constrained. Indeed at overall full employment firms may well collude between themselves or with workers at the expense of consumers, to raise money wages for the sake of industrial peace, triggering off the earnings-prices spiral only too familiar from the wage system (see Tyson, 1977, who suggests this as an explanation of Yugoslav inflation).

A further inflationary impact of over-full employment - if the sharing formula functions as envisaged by Weitzman - is due to its 
inescapably adverse effect on workers' discipline, supply of effort and labour turnover. We know, from the experience of the Soviet and Soviet-type economies characterised by precisely the permanent state of excess demand for labour which Weitzman recommends for the capitalist system, that these adverse effects of over-full employment are endemic and their cost, though difficult to measure, is by no means negligible. (The lesson is two-way: Soviet-type economies should learn that without the parallel introduction of workers' participation in decision making the introduction of sharing components or other firmperformance-related payments, of a kind of ten recommended and implemented in reform projects in these economies, by itself is bound to exacerbate their labour shortage and all the problems associated with its persistence.) Like any other factor lowering labour productivity, these adverse effects of overfull employment will be inflationary.

It is worth stressing that while full employment is a most desirable objective there is no virtue in permanent disequilibrium even of a benign kind like overfull employment. The only advantage is the instantaneous adjustment to a sudden unexpected demand downturn, but there is a continuous price to pay in terms of productivity and anyway, if the world was as Weitzman paints it and if one could persuade economic agents of it, probably if demand dropped from full employment it would be no more difficult to enforce generalised wage restraint by workers or price restraint by firms than to replace the wage contract altogether.

\section{Plausibility: iii) lack of codetermination at overfull employment}

The specific rejection of workers' participation in enterprise decision making - including employment and income distribution - is essential to Weitzman's model (see section 3 above). This is well understood by commentators: "... if it is to work on the Weitzman model, management must retain and even strengthen its right to hire and fire.
This gives the whole idea a more astringent flavour and separates it from the workers' cooperative idea" (Brittan, 1985, p. 12). Lack of codetermination is the ultimate source of the divergence of Weitzman's results from those of conventional theory of income sharing and his only claim to originality. If that assumption is relaxed his results fall; since the whole analysis stands or falls with it, it deserves closer scrutiny.

All Weitzman says here is that he takes "... as given the age-old hallmark of capitalism: private ownership of the means of production, where the decisions on output, employment and pricing are essentially made by capitalists" (1984a, p. 132). "I can see no compelling reason why a capitalist firm should be more prone to allow increased worker participation in company decision making under one contract form than under another" (ibidem, p. 133). "The bargaining power of labor unions is not a natural right" (ibidem, p. 109). "In law and in custom, hiring new workers is a management prerogative, not a mandatory subject to bargaining. ... The share system is a better game than the wage system, but played with strict rules; and one of them is that new workers are welcome to join a share firm" (ibidem, p.110). This is neither evidence nor analysis, it is assertion without foundation in economics or political economy.

Freedom of association is a natural right, or at any rate it is enshrined in law and custom, and the bargaining power of associated labour just as naturally rises, with its relative scarcity, when full employment is approached. If this is not regarded as a compelling reason at full employment, it must become compelling when excess demand for labour arises, let alone when it becomes a permanent, and not just an occasional, feature.

Whether or not Trades Unions exist and whatever are workers' legal rights a permanent labour shortage will give workers an informal 
bargaining power-which they can exercise within the enterprise regardless of their formal position. If and when managerial decisions should disregard substantially the interests of employed workers as they perceive them, workers can retaliate with appropriatedly graded responses ranging from lower work effort to absenteeism to strike and industrial sabotage; the simple tacit threat of response, in the absence of the disciplining and intimidating effect of unemployment, should be enough to assert workers' views of what is good for them as opposed to the views of other, no matter how enlightened. In Poland in 1980-81 workers' informal powers at over-full employment almost brought down a highly centralised power system and could only be stopped by the use of military power and in spite of this forms of self-management have been introduced and are now thriving. Surely overfullemployment strength should be sufficient to obtain self-management in a capitalist society with a liberal and democratic tradition.

Considerable pressure towards an expansion of workers' participation in decision-making would also come from the general participatory climate established by the educational and promotional campaign envisaged by Weitzman. It does not go against the essence of capitalism, on the contrary it is an integral part of the capitalist spirit, that risk-taking should be associated with reward and with power; thus equity shares, unlike preference shares which are more protected from risk, carry a voting right. Weitzman is proposing not the "share economy" but a "non-voting share economy". Why ever should reward and penalty be separated from responsibility? Why ever should workers be exposed to the income risks resulting from decisions in which they have no part, more than they are already exposed in the wage system with respect to employment risks?

Weitzman argues that "... a wage system does not offer labor as a whole a less risky compensation than a share system. It is not true that in a share economy workers are bearing the risk, while in a wage economy firms are bearing the risk. ... The relevant issue is not whether the firms pool of workers should put all their eggs in one basket - they each did that already when they went to work for a single company - but rather which type of basket is more crush-resistant for whom" (1984a, pp. 139-40). Paradoxically Weitzman here rehearses the best case for workers' participation in decision making in the enterprise - a case that holds both under wage and sharing systems. Whatever the relative riskiness of wages and income-shares, there is an underlying risk due to practical limits on the divisibility of the labour services offered by a worker who, unlike the owner of capital, must put all his eggs in only one (or sometimes two) baskets. The case for workers' participation is already there before the introduction of sharing contracts; certainly it is not weakened in any way by the introduction of sharing. It is a case for the "labour-equity economy", recognising that in practice the employment contract. involves an investment decision (and a fairly illiquid investment at that) on the part of both workers and firms.

Unless there is a substantial measure of participation in decision making, Weitzman's remarks on income sharing giving "dignity to the working man and woman, the sense of being significant, useful members of society ..." (1984a, p. 121) sound paternalistic and hollow. There can be no dignity or fulfilment or sense of belonging in being passive objects of other people's decisions; if those feelings were aroused by income sharing, they would certainly promote the demand for codetermination.

It is no accident that the path taken by Weitzman had not been taken before: there are excellent reasons for the conventional association of income sharing with at least a measure of workers' decisional power. That power might be exercised selfishly, or even shortsightedly, but this remains to be proven: there is no empirical evidence of the short term inefficiency and instability of the 1abour-managed firm and economy. One thing is sure: once employed workers have a say, income sharing will not have the effects expected by Weitzman. 
Purely for the sake of argument, suspend now all the objections to the plausibility of Weitzman's model, in order to consider the viability - in the sense of systemic stability - of the model on its own terms.

\section{Viability: i) systemic mergers}

Weitzman briefly refers to the possibility that his model might have systemic instability: "... there is always a temptation for the individual share firm to become a free rider. ... If one share firm converts to a wage contract paling the prevailing level of compensation, it loses nothing and gains the added short-run flexibility of being able to lay off workers freely when its business is bad and take on more of them when business is good. Nor do the workers care that much because there are always jobs available in a share system. ... A share system thus has some tendency to be an unstable social institution under individualistic decision making." (1984a, p. 126).

If one accepts Weitzman's version of how a share economy would function it is hard to see why this should be the case. Contrary to Weitzman's contention, firms confronted with the choice between a wage contract and a sharing agreement yielding equivalent earnings would be wise to adopt the sharing agreement. The firms' ability to "1ay off workers" whenever they wish is presumably identical in both systems (there is no suggestion in Weitzman that share contracts are tenured and if they were there would be far reaching implications which would drastically alter the system and would have to be analysed; Brittan stresses that "... management must retain and even strenghten its right to hire and fire", 1985 p. 12). Before full employment firms would actually have a positive incentive to introduce sharing contracts with parameters initially set to match the current wage, because they would lower the marginal cost of labour below the average cost and be able to expand output and profits; if they do not it is because of worker resistence to the possibility of resulting lower money earnings; in any case workers are risk-averse, so that they would require higher average earnings with a sharing agreement than with the wage contract. At full employment, neither firms nor workers would gain anything from reverting to a wage contract and, if they have already experienced the external economies of sharing contracts, there is no reason to be found in Weitzman's analysis why they should want to disturb current practice. The sharing system would not be introduced spontaneously but, if Weitzman was right, once established would be happily maintained.

The sharing economy à la Weitzman is, as it turns out, "an unstable social institution" and this systemic instability manifests itself in the short, medium and long run, in different forms, to the point of destroying the viability of the system - but not for the reasons Weitzman thinks.

In the short run the system is subject to a concentration process, due to the appearance of system-specific mergers, which makes the system more monopolistic than its capitalist twin. In the Hertzka-Breit-Lange model and in Weitzman labour mobility across firms ensures the equalisation of average earnings throughout the economy. Given differences in the elasticity of net revenue per worker f-curves at those points in different firms, marginal net revenue per worker $R^{\prime}$ (and marginal product of labour) will also differ throughout the economy. The divergence of marginal net revenues per worker is made possible by the decoupling of the marginal and average cost of labour together with the maintenance of a uniform average cost. This causes a short-term inefficiency in labour allocation which, in the longer run, might be eliminated by investment replacing labour up to a uniform rate throughout the economy but which, in the short and medium run, cannot be eliminated by labour redeployment across firms, because sharing firms push employment to the point where net marginal revenue per worker is equal to the basic element of pay, a, and this is said to be firm-specific and vary across 
the economy (though the process determining the relative weight of basic and variable elements of pay is not satisfactorily clarified in Weitzman's writings). If full employment is reached before firms reach the equilibrium point at which $\mathrm{R}^{\prime}=\mathrm{a}$, as long as there are sharing components in workers' earnings (i.e. unless we have $\mathrm{e}=\mathrm{a}=\mathrm{w}$ for all firms, in which case sharing would come to an end, see section 9) there is no reason why any particular value of a should prevail and establish itself throughout the economy; hence net marginal revenue per worker would differ. This short-term micro-inefficiency could be overlooked, in view of the claimed victory over macro-inefficient unemployment and inflation; but an opportunity for the internalisation of the potential gains from redeployment of labour is offered by enterprise mergers:

By merging, share firms starting with different marginal net revenue per worker can redeploy workers from that with lower to that with higher marginal revenue, thus raising joint revenue, altering pay parameters to a new uniform scale corresponding to workers' earnings at least as large as before the merger. The increment in net revenue can be distributed to shareholders, retained, used to raise the earnings of existing employees, or to raise average earnings slightly less but sufficiently to attract more labour to the new firm arising from the merger. Profits from this operation may be temporary but, as Weitzman argues about some other profits said to be "transitory and fleeting", "they are nonetheless real for that" (1984a, p. 120).

The systemic instability generated by mergers of this kind consists in the fact that, in principle, unless we introduce restrictive assumptions on static or dynamic diseconomies of size and growth, or other rigidities, the merger process can continue until the whole economy is encompassed by, if not a single firm, at least a small handful of them (for the analysis of this process in the Hertzka-Breit-Lange model, see Nuti, 1983). The more monopolistic nature of the economy could alter significantly the resulting output, pricing and employment decisions, at least partly offsetting the expected advantages of the share economy.
8. Viability: ii) entry of non-share firms

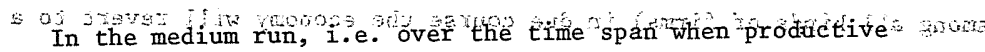

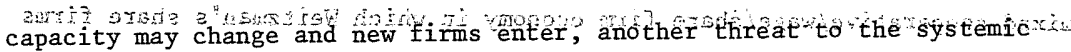
stability of the share ecconomy must cone from the entry of thín-shate firms. Weitzman acknowledges that n...ำ that a new firm would be able to attract labour by offering to pay share

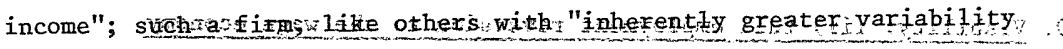
may offset more volatile share income by paying higher than average compensation, or they may just choose to offer wages atone and forgo the tax advantage of the share contract (1984a, p.139). Since workers hired by a new firm have no way of assessing prospective pay they woth have at to be hired on a wage contract, thereby reducing the refative sizenor and the sharing sector in the economy, the more the higher the weight of twos

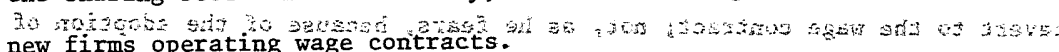

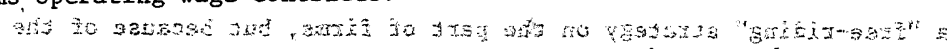

as In the presence of tax advantages of share incomes, however, there is another class of firms at an advantage over Weitzman's share

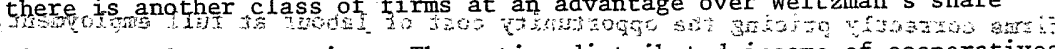
firns, namely cooperatives. The entire distributed income of coperatives is share income and certainly they would be boosted by tax privileges gagd the envisaged educational campaign. However, cooperatives are not share firms in Weitzman's sense for member/workers themselves are in charge and decide the size of membership/employment. Cooperatives members do not regard shared income as cost (section 3 above) and insofar as they maximise anything at all they will be concerned with net revenue per

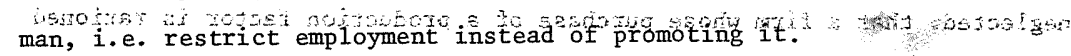

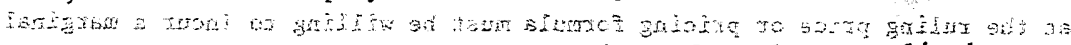
wor ofen Now look at the population of firms after the generalised introduction of share contracts: some will remain wage firm because of revenue volatility; cooperatives will stay as they are; some firms will merge to redeploy labour efficiently and enjoy stronger monopolistic power; new entrants will be wage firms or, more likely, cooperatives. Unless the relative size (appropriately weighted by employment) among new firms of new wage firms later to be transformed into share firms other than 
cooperatives is greater than half (assuming identical mortality rates among all kinds of firms) in due course the economy will revert to a mixed cooperative/wage/share firm economy in which Weitzman's share firms (weighed by employment) are a minority, even if the initial drive towards the new system originally had succeeded.

\section{Viability: iii) full employment reversion to the wage economy}

In the long-run, Weitzman argues, the share economy will settle down to a state of full employment characterised, mutatis mutandis, by the same level of earnings per worker, output, price level and of course employment that would prevail in a wage economy. Contrary to Weitzman's conviction, however, at full employment the share economy would also revert to the wage contract; not, as he fears, because of the adoption of a "free-riding" strategy on the part of firms, but because of the competitive elimination of the sharing element in workers' pay due to firms correctly pricing the opportunity cost of labour at full employment, which is something they do not do, though they should do, in Weitzman's model. He says that "... the best the share firm can do in the long run is to hire labour to the point where its marginal value equals the prevailing pay ..." (1984a, p. 90) whereas he should have said to the point where its marginal value equals its marginal cost.

Inexplicably this elementary piece of neoclassical theory is neglected: that a firm whose purchase of a production factor is rationed at the ruling price or pricing formula must be willing to incur a marginal cost for its acquisition equal to the marginal net revenue obtainable from it. In spite of excess demand for labour at full employment firms are expected not to raise labour earnings over labour marginal productivity at full employment because otherwise their profit would fall. Given the premises this is, of course, correct. What is not correct is the inference that, in view of a sharing component of workers' earnings, basic pay must be lower than the full employment marginal productivity of labour (= full employment equilibrium wage) and therefore there must remain a chronic The assumption of basic pay remaining below the full mployment marginal product of labour is simply incompatible with optimising behaviour on the part of firms; the marginal cost of labour firms is the basic pay and any competent MIT-trained manager will fry, before giving up his search for more workers, offering a higher basic pay, without raising the level of total (basic lus sharing) earnings, knowing that workers are risk-averse and that, therefore, they will gratefully accept, in their pay packet, the substitution of any amount of contractually fixed pay for an identical claim to share income. Put in another form, there are cost savings to be made for a firm offering a contractually fixed sum of money to workers instead of what is to them its certainty-equivalent. But even if workers were risk neutral any self-respecting manager will have to experiment with alternative pay parameters and not rest unless the marginal cost and marginal revenue per worker are equalised, in which case only can he rest assured that he is not missing a profitable opportunity.

a result of this process basic pay $\underline{a}$, which is the marginal cost to firms of acquiring new workers, will be made to coincide with full employment marginal revenue product of labour w throughout the conomy. At that point, the sharing element of workers' earnings vanishes and with it Weitzman's share economy. This is a far more fundamental systemic instability than that contemplated by Weitzman,-i.e. the attraction for firms of retaining the "short-run flexibility of being able to lay off workers" (1984a, p. 139) - a flexibility which they neither lose nor, if the share economy worked as Weitzman expects, in any case would need. Even if none of the objections raised in the previous sections applied, and the diffusion of share contracts was able to deliver full employment, in the long run (which is not even very long, since Weitzman assumes that sharing coefficients are revised "once a year", 1983, p. 769) 
the system will revert to a wage economy. At best, therefore, Weitzman's model is one of a soft-landing on full employment through initial reductions in the money earnings of workers, not as drastic as would be necessary under wage contracts and, therefore, more likely to be acceptable to workers, though eventually full employment money and real earnings would be the same under either system.

But suppose money wage flexibility was sufficient to obtain full employment, and fuller employment obtained through lower money wages was associated with lower prices and higher real earnings and real incomes all round, and no other objections held, and the government had to make substantial tax concessions to introduce the new system and reap a most desirable external effect or "public good". Then why not simply use the same fiscal resources to introduce a wage subsidy instead, first on a small scale and afterwards, as employment rises and prices fall boosting real incomes, on an ever incleasing scale financed out of the taxation of resulting real income increases, up to full employment? Neither firms nor workers could possibly object, the public good would be purchased, as it should be, out of the public purse but at no real cost to the public under the postulated assumptions. This proposal would have all the advantages of Weitzman's scheme, without many of the disadvantages such as the drawbacks of overfull employment, or the inefficient deployment of labour, or monopolistic tendencies - if of course the underlying assumptions are correct, while if not correct this would become apparent at the first round of wage subsidies which then would be stopped without having done any harm, without the dangerous frustration that would follow the (probable) failure of the economy-wide introduction of share contracts. ${ }^{1}$

1. For alternative institutional innovations, which do not require but are compatible with the assumptions underlying Weitzman's model, see Nuti, 1985.

\section{Conclusions}

Workers' participation in enterprise revenue or profit has been introduced in modern capitalism, historically, "as a way of building employee loyalty, thus avoiding industrial unrest and unions" as well as "a way of putting the employee on the side of management, thereby boosting production and efficiency", thus being unpopular with Trades Unions (Mitche11, 1985, p.38). Weitzman proposes the economy-wide diffusion of sharing contracts relating at least a substantial part of workers' earnings to the performance of their enterprise. In economies characterised by sufficient plant to employ the whole work force and by generalised monopolistic competition, the large scale introduction of share contracts in place of wages is expected to rapidly lead to full employment, lower prices and permanent excess demand for labour which is not inflationary and absorbs partly or wholly the shocks of demand recession (Weitzman, 1983, 1984a, 1984b, 1985).

Both the plausibility of Weitzman's assumptions and the model's viability - understood as the system's capacity to reproduce its institutional features once it is introduced - are doubtful on several grounds. Usually one good reason for rejecting a case is sufficient, but the strength of conviction with which the scheme has been put forward, the importance of its claims and the favour it has recejved justify the extensive treatment of both the mode1's assumptions and functioning.

Weitzman's model implicitly assumes the absence of classical unemployment (i.e. marginal product of labour reaching zero before full employment is reached) and keynesian unemployment (i.e. marginal revenue of firms reaching zero before full employment). Income sharing at least initially will discourage investment by lowering the incentive to replace labour which is being made marginally cheaper, thereby slowing down the absorption of classical unemployment and possibly offsetting the positive impact of income sharing on consumption demand. 
If share contracts did succeed in raising employment and output, multiplier and accelerator effects might revamp inflation in spite of sharing; while, if full employment was reached and the envisaged excess demand for labour established and maintained, firms facing the ensuing bargaining pressure of labour may collude between themselves or with workers at the expense of consumers to raise prices and earnings. Moreover, persistent excess demand for labour will lower productivity through higher labour turnover and absenteeism and lower discipline and supply of effort, pushing up costs and prices.

It is neither feasible nor desirable to expose workers to the risks of income sharing without parallel expansion of their participation in enterprise decision making. The formal and informal bargaining power of workers at full employment with excess demand for labour will demand and obtain forms of codetermination, which will bring share contracts closer to the cooperative model, well known for its restrictive employment and output policies.

Even if none of these objections applied, the model would not be viable, i.e. would not maintain its distinguishing institutional features, whether in the short, lhe medium or the long run.

In the short run the equalisation of earnings per workers through labour mobility will lead to diverging marginal product or marginal net revenue per worker; this inefficiency in labour deployment cannot be eliminated other than through enterprise mergers, which raise considerably the monopolistic character of the share economy.

In the medium run, new firms will be either wage firms (because workers hired by a new firm have no way of assessing prospective pay) or cooperatives (which can take fuller advantage of the proposed privileged tax treatment of share income). Unless specific conditions are satisfied concerning the proportions of various kinds of firms entering, changing or dying are satisfied, the weight of share firms will gradually dwindle.
In the long run, at full employment, average earnings are pegged to the full employment marginal revenue product of labour but competing firms have an incentive to raise the fixed component of pay - which is the marginal cost of labour to firms - up to the marginal net revenue p. of 1 abour, thus reducing the sharing component of earnings to zero. At best, i.e. if none of the other objectionscounted, the proposal would allow full employment to be reached through the downwards flexibility of labour earnings offered by the share system, but with smaller cuts in money ablain full employment through money wage cuts, thereby raising the probability of cuts being accepted.

Is there an alternative way of defeating both unemployment and inflation? If we are to believe Weitzman's account of how the economy works there certainly is: a wage subsidy would have the same effects on employment, output and prices, and if it was introduced at first on a small scale it would boost real incomes enabling the government to expand the scale of wage subsidies financed out of additional tax revenue until full employment was reached; any displacement from full employment would be dealt with in the same way if and when it occurred, without the drawbacks of permanent labour shortage.

None of what precedes should be understood or construed as a citicis per se, but of its introduction on a substantial without the parallel expansion of workers' participation in enterprise decision making without which substantial income sharing would involve a regress to pre-capitalistic conditions, and of the gross overclaims for its expected achievements put out by Weitzman. The dependence of the smaller part of workers' earnings from their enterprise performance, or better still from the overall economy's performance, accompanied by forms of workers' codetermination, can have - if the terms are right - beneficial effects on productivity and be an attractive counterpart for workers' acceptance of the austerity policies which may be necessary to reach and maintain full employment without excessive inflation. 


\section{;REFERENCES}

ALEXANDER, C.P. (1985), "Search for a miracle cure", Time Magazine, 20 May

BREIT M.-LANGE O. (1982), "Un modello di economia socialista di mercato autogestita con garanzia di pieno impiego e di uguaglianza distributiva", Rivista internazionale di Scienze sociali, XC, n.3,pp.301-4

BARTLETT W.-UVALIC M. (1985), "Bibliography on labour-managed firms and employee participation", Fourth International Conference on the Economics of Self-Management, CIRIEC, Liège, 15-17 July

BRITTAN S. (1985), "Profit sharing: the link with jobs", Financial Times, Monday February 25, London

DOMAR E.D. (1966), "The Soviet collective farm as a producer cooperative" American Economic Review, LVI, n.4, pp. 737-757

HERTZKA T. (1891), Freeland: a social anticipation, Chatto \& Windus, London

LANE D. (1985), Employment and labour in the USSR, Harvester Press, London

MITCHELL D.J.B. (1985), "Wage flexibility in the United States: lessons from the past", American Economic Review, Papers and Proceedings, LXXV, n. 2, May, pp. 36-40

NUTI D.M. (1983), "Fusioni di imprese ed efficienza nei modelli di economie autogestite", Rivista internazionale di Scienze sociali, XCI, n. 4, pp. 487-494

NUTI D.M. (1985), "Economic planning in market economies: scope, instruments, institutions", EUI Working Paper n. 85/180, Florence,July (Italian translation in Politica ed Economia, n.7-8, July-August 1985, pp. 63-70

TYSON L. (1977), "The Yugoslav inflation: some competing hypotheses", Journal of Comparatide Economics, I, n.2, pp. 113-146

VANEK J. (1970), The General Theory of Labor-Managed Market Economies, Cornel1 University Press, Ithaca (N.Y.)

WARD B.M. (1958), "The firm in Illyria: market syndicalism", American Economic Review, XLVIII, n.4, pp. 566-589

WEITZMAN M.L. (1983), "Some macroeconomic implications of alternative compensation systems", Economic Journa1, XCIII, n.4, pp. 763-783

WEITZMAN M.I. (1984a), The share economy, Harvard University Press, Cambridge

WEITZMAN M.L. (1984b), "The simple macroeconomics of profit-sharing", MIT Working Paper n. 35.7, December, Cambridge Mass.

WEITZMAN M.L. (1985), "Profit sharing as macroeconomic policy", American Economic Review, Papers and Proceedings, LXXV, n.2, May, pp. 41-45 